All this week's Correspondence was written in response to the Editorial 'Venezuela's way ahead' (Nature 450, 922; 2007).

\section{Venezuelan students are campaigning for freedom}

SIR - You indicate that President Hugo Chávez has broadly supported universities and scientific research (Nature 450, 922; 2007). But you report that his proposals to bolster his powers and retain his position indefinitely have been met with opposition, spearheaded by protest marches of hundreds of thousands of students and their professors.

As rector of Simón Bolívar University and vice-president of Venezuela's Academy of Physical, Mathematical and Natural Sciences, I disagree with your suggested explanation for this apparent inconsistency, that students in public Venezuelan universities are mostly from the upper middle class.

All students, rich and poor, dislike authoritarian regimes. Student protests were sparked off in May after Chávez ordered the closure of a major television station whose views opposed those of his government. Students demand freedom of speech and confronted with the president's insistence on imposing a narrow-minded Cuban-style socialist state on Venezuela - freedom of choice. They want universities to stay autonomous and free from government intervention. Their fight is not about leftwing or right-wing politics, but to reconcile opposing and radical views in the interests of their own future.

Benjamin Scharifker

Universidad Simón Bolívar, Apartado 89000 , Caracas 1080A, Venezuela, and Academia de Ciencias Físicas, Matemáticas y Naturales, Palacio de las Academias, Avenida Universidad, Caracas 1010, Venezuela

\section{Independent institutes are being financially strangled}

SIR - Many of the assumptions made in your Editorial 'Venezuela's way ahead' about government benevolence (Nature 450, 922; 2007) overlook the realities. Although substantial funds are potentially available for research, support is not as widespread or as academically competitive as you imply.

Universities not under direct government control are being financially strangled. One example is the country's largest university, the Central University of Venezuela, whose budget allocation has been unchanged for four years, although the country has the highest inflation in South America (its "rapid economic growth" is mostly the result of massive state spending, supported by an ever-increasing reliance on oil income, not a consequence of real productivity). This year, the university is precluded from hiring new staff and promotions are ruled out.

There is no class struggle at Venezuelan public universities, which are free and have a nationwide entrance exam. Some private institutions give scholarships and levelling courses for underprivileged students. Venezuelan students are simply supporting universal rights such as freedom of expression and academic freedom, and taking a firm stance against political discrimination, coercion and imposition of a single ideology.

Governments distributed competitive research grants before Chávez came to power, but now political criteria are more important and the system is being undermined. Given autonomous universities' failure to elect government-sponsored candidates to governing bodies, the state has resorted to physical, legal and financial harassment. The proposed constitution criticized by the student movement could eventually destroy administrative and academic autonomy.

Referendum results have raised hopes of reconciliation and decreasing political polarization, and of slowing the exodus of talented young Venezuelans.

Name and address supplied. The author is a research professor at a Venezuelan university.

\section{Government control has weakened universities}

SIR - Further to your Editorial (Nature $450,922 ; 2007)$, the academic freedom of Venezuela's autonomous universities, where some $90 \%$ of all scientific research in the country is carried out, has come under attack by the present government, which has opened a competing and parallel university system of questionable academic quality.

Contrary to what you imply, President Chávez has weakened the universities in his efforts to bring them all under government control. The country's premier research institute, the Venezuelan Institute for Scientific Research in Caracas, for example, is now under the control of the government, which plans to incorporate it into another submissive academic unit. Few departments at Venezuela's 47 universities have the staff and equipment for internationally competitive research.

It is not clear that Venezuelans will be able to "build on some of [the president's] genuine achievements" because many Venezuelans are in doubt about what these achievements are. In my area of expertise, government policies are hurting the meagre but honourable academic productivity of my country.

\section{Orlando Albornoz}

Universidad Central de Venezuela, Apartado No 50.061, Caracas 1050-A, Venezuela

\section{Social sciences worst off as projects remain unfunded}

SIR - Your Editorial (Nature 450, 922; 2007) brings welcome attention to Venezuelan science and to the defeat of President Chávez's proposed reforms to allow himself to stay in power indefinitely. But I do not agree with your remarks about resources.

Students are not all from upper-middleclass backgrounds - a social category that Chávez has removed anyway, by quenching private enterprise. For decades, university students have been drawn from the middle and lower classes, and all the more so now, when the Gucci-clad revolutionary leaders claim that nearly a million of the country's 26 million people are studying at university.

The Organic Law of Science, Technology and Innovation (LOCTI) may support some worthwhile projects, but they are funded by compulsory tax deductions that otherwise would go to the Ministry of Science and Technology, largely known for its incapacity to administer anything. Last year, it failed to spend $75 \%$ of its budget. Current government policy is to use LOCTI funds to pay science and technology research grants, but hundreds of sound scientific projects - especially in social sciences - go unfunded. During 2006, the only available source of funding for science was the Misión Ciencia, a presidential initiative, as the government did not support other funding opportunities.

\section{Jaime Requena}

Academia de Ciencias Físicas, Matemáticas y Naturales, Palacio de las Academias, Esquina de San Francisco, Caracas 1010, Venezuela

\section{Grants awarded on the basis of political criteria}

SIR - Your Editorial about Venezuela seems very optimistic (Nature 450, 922; 2007). You point out that the present government created the Ministry of Science and Technology, claiming that this "distributes grant money on a competitive basis".

In fact, the ministry was set up to replace CONICIT, the national council for scientific and technological research: an autonomous institution of almost 30 years' standing that did indeed use peer review and scientific excellence as criteria for distributing grants. The present ministry, however, emphasizes political criteria when assigning grants.

Venezuela's share of scientific publications, as measured by PubMed, fell from $0.054 \%$ in 1998 (the year before Chávez became president) to $0.04 \%$ in 2006 .

\section{Klaus Jaffe}

American Center for Strategic Studies, Universidad Simón Bolívar, Apartado 89000 , Caracas 1080, Venezuela 